\title{
IDENTIFICATION, CHARACTERIZATION AND ANTIBACTERIAL POTENTIAL OF PROBIOTIC LACTIC ACID BACTERIA ISOLATED FROM NANIURA (A TRADITIONAL BATAK FERMENTED FOOD FROM CARP) AGAINST Salmonella typhi
}

\author{
G. Haro ${ }^{1}$, I. Iksen ${ }^{2, *}$, and N. Nasri ${ }^{3}$ \\ ${ }^{1}$ Department of Pharmaceutical Chemistry, Faculty of Pharmacy, Universitas Sumatera Utara, \\ Medan-20155, Indonesia \\ ${ }^{2}$ Department of Pharmacy, Sekolah Tinggi Ilmu Kesehatan Senior Medan, \\ Medan-20141, Indonesia \\ ${ }^{3}$ Department of Pharmaceutical Biology, Faculty of Pharmacy, Universitas Sumatera Utara, \\ Medan-20155, Indonesia \\ *E-mail: ikseniksen08@gmail.com
}

\begin{abstract}
Carp is a freshwater fish that can be processed into a fermented food called Naniura which is popular among Bataks. Only a little research has been conducted on this food. Due to a lack of information in Indonesia, this study was conducted to isolate, characterize and investigating antibacterial potential against Salmonella typhi. Probiotic lactic acid bacteria (LAB) were isolated by the sprinkling dilution method on the MRS medium. Then tested the characteristics of LAB isolates including gram staining, catalase test, TSIA test, fermentation type, motility test, and growth at temperatures of $15^{\circ} \mathrm{C}, 37^{\circ} \mathrm{C}$ and $45^{\circ} \mathrm{C}$ in MRSB and antibacterial power test against Salmonella typhi with agar diffusion method. The results showed that the probiotic LAB isolates produced had the same characteristics as the Lactobacillus group which were gram-positive, in the form of a stem/chain stem, negative catalase, not motile, homofermentative, and capable of reducing glucose. The diameter of the inhibition zone produced is categorized as strong with an average inhibition zone of $100 \%$ at $12.9 \mathrm{~mm} \pm 0.30$ with a concentration of $10^{6} \mathrm{CFU} / \mathrm{mL}$. This study showed that Lactobacillus strains with good antibacterial activity against Salmonella typhi could be isolated from Naniura.
\end{abstract}

Keywords: Probiotic, Lactic Acid Bacteria, Naniura, Antibacterial, Salmonella typhi

(C) RASĀYAN. All rights reserved

\section{INTRODUCTION}

Probiotics are live microorganisms that are intended to have health benefits and can be formulated into many different types of products, including foods, drugs, beauty products and dietary supplements. Species of Lactobacillus and Bifidobacterium are most commonly used as probiotics, but the yeast Saccharomyces cerevisiae and some E. coli and Bacillus species are also used as probiotics. Lactic acid bacteria, including Lactobacillus species, which have been used for preservation of food by fermentation for thousands of years, can serve a dual function by acting as agents for food fermentation and in addition, potentially imparting health benefits. Strictly speaking, however, the term "probiotic" should be reserved for live microbes that have been shown in controlled human studies to impart a health benefit. Fermentation of food provides characteristic taste profiles and lowers the $\mathrm{pH}$, which prevents contamination by potential pathogens. Fermentation is globally applied in the preservation of a range of raw agricultural materials (cereals, roots, tubers, fruit and vegetables, milk, meat, fish etc.) ${ }^{1-3}$ Probiotic bacteria have become increasingly popular during the last two decades as a result of the continuously

Rasayan J. Chem., 13(1), 464-468(2020)

http://dx.doi.org/10.31788/RJC.2020.1315530

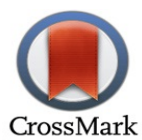


RASĀYAN J. Chem.

Vol. 13 | No. 1 |464 - 468| January - March | 2020

expanding scientific evidence pointing to their beneficial effects on human health. ${ }^{4}$ One of the source of probiotic is the lactic acid bacteria (LAB) which can be found in various fermented foods. One of the food is called Naniura which is popular among Bataks. Naniura is made by soaking carp in jungga acid. By processing carp into Naniura, it can inhibit and kill pathogenic bacteria that cannot survive acidic $\mathrm{pH}$ conditions, but lactic acid bacteria can survive acidic $\mathrm{pH}$.

One of the pathogenic bacteria that can cause systemic infections acute in the small intestine is Salmonella enterica serotype typhi (Salmonella typhi). A disease that can be caused by Salmonella typhi is typhoid fever. Risk factors for typhoid fever are poor environmental sanitation, poor individual hygiene, consuming food (vegetables) in raw conditions and drink water that is not boiled first. ${ }^{5}$ Based on the description above, the authors conducted research to find out probiotic LAB antibacterial activity obtained from Naniura fish against bacteria Salmonella typhi.

\section{EXPERIMENTAL}

\section{Sample Collection and Preparation}

Naniura was made by draining carp, put it into a container then watered with jungga acid in the ratio of 1 g jungga acid to $1.8 \mathrm{~g}$ carp meat and 3\% salt added. The carp was immersed for 7 hours then added to all the herbs. ${ }^{6}$

\section{Isolation of LAB from Naniura}

Isolation of LAB from naniura was done by serial dilution agar technique on MRSB media. $1 \mathrm{~g}$ of naniura meat was dissolved in $9 \mathrm{~mL}$ of MRSB, homogenized by using vortex and incubated at $37^{\circ} \mathrm{C}$ for $24-48 \mathrm{hrs}$. $1 \mathrm{~mL}$ of incubation result was taken and put into a tube that has been containing $9 \mathrm{~mL}$ of PDF media and homogenized using vortex. Serial dilution of $10^{-2}$ until $10^{-10}$ was made by pipetting $1 \mathrm{~mL}$ into $9 \mathrm{~mL}$ of PDF. From each dilution, pipette $1 \mathrm{~mL}$, put it into petri dish then poured $15 \mathrm{~mL}$ of MRSA $+1 \% \mathrm{CaCO}_{3}$ and incubated at $37^{\circ} \mathrm{C}$ for $24-48 \mathrm{hrs}$ for the bacterial growth. The isolate showing that the clear zone around the colony is thought to be the LAB. This colony is taken and transferred using an ose needle on the media. Incubation and isolation were repeated 3 times until obtained pure culture. ${ }^{6-8}$

\section{Characterization of LAB}

The characteristics determined including gram staining, catalase test, Triple Sugar Iron test, fermentation type, motility test, and growth at temperatures of $15^{\circ} \mathrm{C}, 37^{\circ} \mathrm{C}$ and $45^{\circ} \mathrm{C}$ in MRSB media. The characteristics of $\mathrm{LAB}$ is done by standard procedures that are generally accepted. ${ }^{6,9}$

\section{Antibacterial Testing of LAB Against Salmonella typhi}

LAB antibacterial activity against $S$. typhi (ATCC 14028) is carried out by the disk diffusion method on MRSA plates. A $50 \mu \mathrm{L}$ suspension of LAB was spread on MRS for each concentration, then left for 15 mins and incubated in an incubator at $35 \pm 2^{\circ} \mathrm{C}$ for $18-24 \mathrm{hrs}$. All the data were expressed as mean $\pm \mathrm{SD} .{ }^{10-}$ 12

\section{Isolation of $\mathbf{L A B}$}

\section{RESULTS AND DISCUSSION}

LAB isolation was carried out using selective Lactobacillus media namely MRSB and MRSA. In this study, we used MRSA media which added $1 \%$ by $\mathrm{CaCO}_{3}$. The isolation results in this study obtained 1 isolate of LAB whose colonies oval-shaped with rounded colony edges, flat surface height and creamy white colonies by providing a clear zone around it. Selection LAB using MRSA media plus $1 \% \mathrm{CaCO}_{3}$ can be marked in the presence of a clear zone around the colony after 2-3 days of incubation. BAL produces lactic acid which when reacting with $\mathrm{CaCO}_{3}$ will produce calcium lactate is dissolved in the media and gives rise to a clear zone. ${ }^{13,14}$ Image result of LAB and the gram staining can be seen in Fig-1.

\section{Characterization of LAB}

Characterization of LAB isolates was carried out morphologically by observing the form of bacterial colonies on the media visually and microscopically with Gram staining. Biochemical tests include 
RASĀYAN J. Chem.

Vol. 13 | No. 1 |464 - 468| January - March | 2020

catalase tests, Triple tests Sugar Iron Agar (TSIA), fermentation type test, motility test, and growth temperature test. The results of the characterization of lactic acid bacteria can be seen in Table-1.
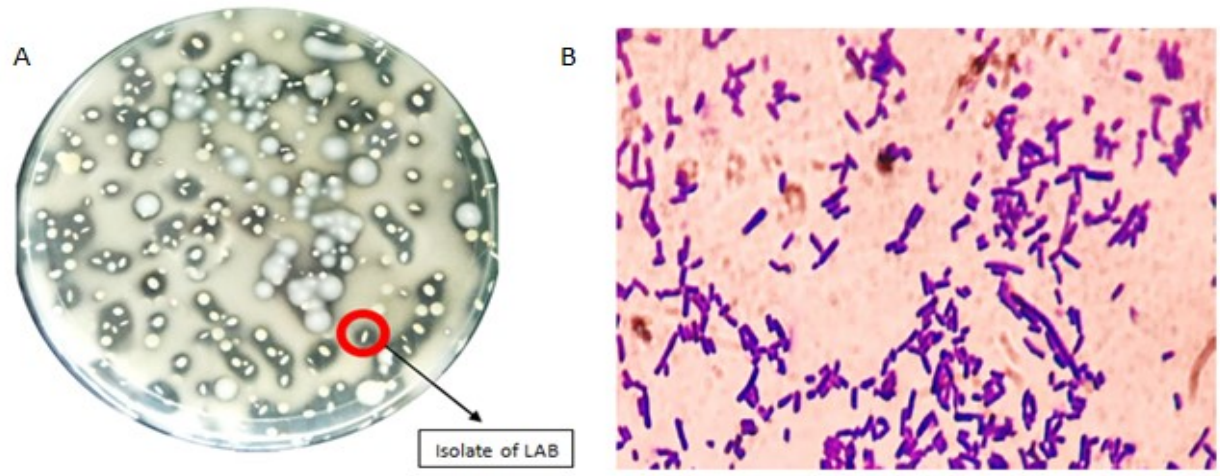

Fig.-1: A: Isolate of LAB; B: Gram Staining of LAB

Table-1: Characteristics of LAB

\begin{tabular}{|c|c|c|}
\hline No & Characteristics & Isolate of LAB \\
\hline \multicolumn{3}{|c|}{ Morphology of the Colony } \\
\hline 1 & Colony shape & Oval \\
\hline 2 & The shape of the edge of the colony & Rounded \\
\hline 3 & Surface height & Flat \\
\hline 4 & Colony color & Creamy white \\
\hline \multicolumn{3}{|c|}{ Cell Morphology } \\
\hline 1 & Gram & + (purple) \\
\hline 2 & Cell shape & Rod \\
\hline \multicolumn{3}{|c|}{ Biochemical Test } \\
\hline 1 & Catalase & - \\
\hline 2 & Triple Sugar Iron & + \\
\hline 3 & Fermentation type & - \\
\hline 4 & Gas & - \\
\hline 5 & $\mathrm{H}_{2} \mathrm{~S}$ & - \\
\hline 6 & Motility & - \\
\hline \multicolumn{3}{|c|}{ Growth Temperature } \\
\hline 1 & $15^{\circ} \mathrm{C}$ & - \\
\hline 2 & $37^{\circ} \mathrm{C}$ & ++ \\
\hline 3 & $45^{\circ} \mathrm{C}$ & +++ \\
\hline
\end{tabular}

Information: (-) : Negative result; $(+)$ : Positive result with small amount; $(++)$ : Positive result with moderate amount; $(+++)$ : Positive result with large amount

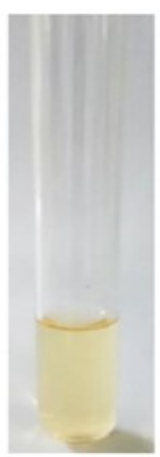

A

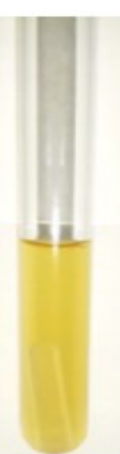

B

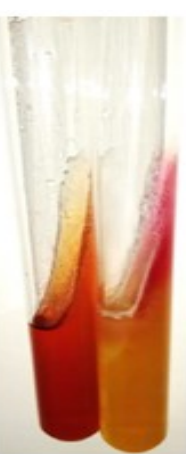

$\mathrm{C}$

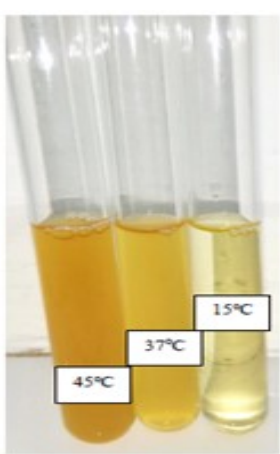

D

Fig-2: A: Motility Test Result; B: Fermentation Type Test; C: TSIA Test;

D: Growth Temperature Test in $15^{\circ} \mathrm{C}, 37^{\circ} \mathrm{C}$ and $45^{\circ} \mathrm{C}$ 
RASĀYAN J. Chem.

Vol. 13 | No. 1 |464 - 468| January - March | 2020

In the catalase test gave negative results, the $\mathrm{LAB}$ isolates were absent visible gas bubbles when given 2-3 drops $\mathrm{H}_{2} \mathrm{O}_{2} 3 \%$. The catalase test is a test to identify microbes that are able to produce the catalase enzyme which is used to break down $\mathrm{H}_{2} \mathrm{O}_{2}$ formed from aerobic respiration and are toxic to bacteria, become $\mathrm{H}_{2} \mathrm{O}$ and $\mathrm{O}_{2}$ which are no longer toxic. ${ }^{15}$

The Triple Sugar Iron Agar (TSIA) test showed positive results on LAB isolates. Isolate of LAB is able to ferment the glucose, sucrose, and lactose contained in TSIA medium and produce acids which are indicated by changes in color turn yellow. TSIA test is a biochemical test to find out

the ability of microbes to ferment sugars, sucrose and lactose contained in the medium. From the test results, it was shown that the isolate was not produced gas and not produce $\mathrm{H}_{2} \mathrm{~S}$, Freeman (1979) states that genus Lactobacillus does not produce $\mathrm{H}_{2} \mathrm{~S}$.

The type of fermentation test shows that the isolates are homofermentative because it shows negative results on a durham tube marked by not producing gas bubbles. The motility test showed negative results or non-motile nature. This matter can be seen in the absence of movement of bacteria that resembles propagation roots around the puncture area on the media. LAB has a very limited biosynthetic ability. The acquisition of energy solely depends on the fermentative metabolism carried out in its place. ${ }^{15}$

The growth temperature test showed that LAB isolates were seen the best growing is at a temperature of $45^{\circ} \mathrm{C}$ with marked turbidity formed on MRSB media. While at $15^{\circ} \mathrm{C}$ it is not visible bacterial growth with clear MRSB media. And at temperature $37^{\circ} \mathrm{C}$ shows the growth of bacteria but not turbid at $45^{\circ} \mathrm{C}$. Based on the optimum temperature for bacterial growth, LAB is grouped into two groups, namely mesophilic (optimum growth temperature of $25^{\circ} \mathrm{C}$ and temperature maximum $40^{\circ} \mathrm{C}$ ) and thermophilic (optimum growth temperature of $37^{\circ} \mathrm{C}$ and temperature the maximum is $\left.52^{\circ} \mathrm{C}\right) .{ }^{15}$ The image result of LAB characteristics can be seen in Fig-2.

\section{Antibacterial Activity of LAB Against $S$. typhi}

Based on the results of measurements of antibacterial activity seen in Table- 3 the minimum inhibitory concentration (MIC) of the LAB inoculum was obtained which is $12.5 \%$. Bacterial classification based on the degree of inhibition zone divided into 3 groups, namely moderate (moderate inhibition zone) that is 6$9 \mathrm{~mm}$, Strong inhibition zone $(10-14 \mathrm{~mm})$ and very strong inhibition zone $(15-18 \mathrm{~mm})$.

Table-3: Inhibition Zone of S. typhi

\begin{tabular}{c|c|c}
\hline No & LAB Inoculum Concentration $(\% \mathrm{v} / \mathrm{v})$ & Diameter $(\mathrm{mm}) \pm \mathrm{SD}(\mathrm{n}=3)$ \\
\hline 1 & $100\left(1,00 \times 10^{6} \mathrm{CFU} / \mathrm{mL}\right)$ & $12.9 \pm 0.3$ \\
\hline 2 & $75\left(0.75 \times 10^{6} \mathrm{CFU} / \mathrm{mL}\right)$ & $11.6 \pm 0.25$ \\
\hline 3 & $50\left(0.50 \times 10^{6} \mathrm{CFU} / \mathrm{mL}\right)$ & $9.8 \pm 0.15$ \\
\hline 4 & $25\left(0.25 \times 10^{6} \mathrm{CFU} / \mathrm{mL}\right)$ & $8.3 \pm 0.25$ \\
\hline 5 & $12.5\left(0.125 \times 10^{6} \mathrm{CFU} / \mathrm{mL}\right)$ & - \\
\hline 6 & $6.25\left(0.0625 \times 10^{6} \mathrm{CFU} / \mathrm{mL}\right)$ & - \\
\hline 7 & $3.123\left(0.03125 \times 10^{6} \mathrm{CFU} / \mathrm{mL}\right)$ & - \\
\hline 8 & $\mathrm{NaCl} 0.9 \%$ &
\end{tabular}

Values are given as mean \pm SD for three replicate in each group.

In general, gram-negative bacteria have a cell wall structure more complex, namely the outer layer in the form of lipopolysaccharides and the inner layer in the form peptidoglycan so that it has better resistance to compounds antimicrobial. Organic acids, especially lactic acid, are bactericidal at $\mathrm{pH} 4.5$ with concentrations above $0.2 \% .{ }^{16}$ Probiotic bacteria which are lactic acid bacteria that produce metabolite compounds that function as antimicrobials. The fermentation process of LAB involves have a characteristic that is accumulated of organic acids which are companied by a decrease in $\mathrm{pH}$. The antimicrobial effect of organic acid is a result of a decrease in $\mathrm{pH}$ value and is also not dissociated from organic acid molecules. ${ }^{17,18}$ Lactic acid diffuses into the growing media of test bacteria that can disrupt the integrity of the pathogenic bacterial cell membrane. Damage to cell membranes resulting in nutrients that are needed for testing bacteria to grow absorbed so that the metabolic process does not work and its growth will be hampered. Differences in LAB antimicrobial activity against several test microbes 


\section{RASĀYAN J. Chem.}

Vol. 13 | No. 1 |464 - 468| January - March | 2020

based on differences in the structure of microbial cell wall compilers, different antimicrobial compounds also provide different inhibitory zones at a certain time. ${ }^{19-21}$

\section{CONCLUSION}

The processing of carp into naniura can produce food that contains probiotic LAB (Lactobacilus group) which have antibacterial activity against Salmonella typhi with a strong inhibition zone.

\section{ACKNOWLEDGMENT}

The authors wish to thank Faculty of Pharmacy Universitas Sumatera Utara for the support in this research

\section{REFERENCES}

1. R. Eid, J. El Jakee, A. Rashidy, H. Asfour, S. Omara, M.M Kandil, et al., Journal of Probiotics \& Health, 4(2), 138 (2016), DOI:10.4172/2329-8901.1000138

2. I.M. Aasen, T. Møretrø, T. Katla, L. Axelsson and I. Storrø, Applied Microbiology and Biotechnology, 53(2), 1159 (2000), DOI:10.1007/s002530050003

3. M. Kechagia, D. Basoulis, S. Konstantopoulou, D. Dimitriadi, K. Gyftopoulou,N. Skarmoutsou, et al., ISRN Nutrition, 2013, 481651 (2013), DOI:10.5402/2013/481651

4. S.H. Khan and F.A. Ansari, Pakistan Journal of Pharmaceutical Sciences, 20(1), 76 (2007).

5. O.P. Permatasari, Jurnal Kesehatan Masyarakat, 2(1), 1 (2013).

6. M. Manik, Disertation Faculty of Mathemactics and Natural Sciences, University of Sumatera Utara, Medan, North Sumatera, Indonesia (2017).

7. R.K. Pundir, S. Rana, N. Kashyap and A. Kaur, Journal of Applied Pharmaceutical Sciences, 3(3), 85 (2013), DOI:10.7324/JAPS.2013.30317

8. E.Z. Mirzaei, E. Lashani and A. Davoodabadi, GMS Hygiene and Infection Control, 13, 1 (2018), DOI: $10.3205 /$ dgkh000307

9. B.A. Adeniyi, A. Adetoye and F.A. Ayeni, African Health Sciences, 15(3), 888 (2015).

10. M. Gopalakrishnan, A. Sheenu, B. Varghese, J. Dharani and S. Saraya, Rasayan Journal of Chemistry, 12(3), 1072 (2019), DOI: 10.31788/RJC.2019.1235136

11. M. Toshniwal, M. Bundel, P. Kriplani, R. Ravikant, R. Pareek and A. Pareek, Rasayan Journal of Chemistry, 12(3), 1294 (2019), DOI:10.31788/RJC.2019.1235207

12. T. Okselni, A. Santoni, A. Dharma and M. Efdi, Rasayan Journal of Chemistry, 12(2), 146 (2019), DOI: $10.31788 /$ RJC.2019.1215019

13. S.M. Chang, C.L. Tsai, W.C. Wee and T.R. Yan, African Journal of Microbilogy Research, 7(8), 683 (2013).

14. H.J. Lay and U. Satiman, International Journal of ChemTech Research, 8(12), 630 (2015).

15. I.S. Surono, Probiotik Susu Fermentasi dan Kesehatan, Tri Cipta Karya, p 25 (2004).

16. L. Topisirovic, M. Kojic, D. Fira, N. Golic, I. Strahinic and J. Lozo, International Journal of Food Microbiology, 112(3), 230 (2006), DOI:10.1016/j.ijfoodmicro.2006.04.009

17. A. Mezaini, N.E. Chihib, A.D. Bouras, N.N. Arroume and J.P. Hornez, Journal of Environmental and Public Health, 2009, 678495 (2009), DOI: 10.1155/2009/678495

18. J. Lozo, M. Vukasinovic, I. Strahinic and L. Topisirovic, Journal of Food Protection, 67(12), 2727 (2004), DOI:10.4315/0362-028x-67.12.2727

19. K. Bendjeddou, M. Fons, P. Strocker and D. Sadoun, World Journal of Microbiology and Biotechnology, 28(4), 1543 (2012), DOI:10.1007/s11274-011-0958-1

20. D. Ren, J. Zhu, S. Gong, H. Liu and H. Yu, BioMEd Research International, 2018, 1(2018) DOI: $10.1155 / 2018 / 5416725$

21. L. González, H. Sandoval, N. Sacristán, J.M. Castro, J.M. Fresno and M.E. Tornadiji, Food Control, 18(6), 716 (2007), DOI:10.1016/j.foodcont.2006.03.008

[RJC-5530/2019] 